\title{
Considerações sobre encontros científicos e o significado da itinerância
}

\author{
Soraya ALmeida
}

Setor de Petrologia, Depto. Geociências UFRRJ, Seropédica, RJ. - salmeida1966@gmail.com

\author{
Manuscrito: \\ Recebido: 6/10/2016 \\ Corrigido: $31 / 10 / 2016$ \\ Aceito: 1/11/2016
}

Citation: Almeida S. 2016. Considerações sobre encontros científicos e o significado da itinerância. Terræ Didatica, 13(1):62-63. < http:// www.ige.unicamp.br/terraedidatica/>.

A Royal Society of London foi criada em 1660 com o objetivo de promover o conhecimento científico seguindo os preceitos de uma nova forma de pensar e fazer ciência tendo como referência os moldes concebidos por Francis Bacon. Para ser admitido como membro era necessário que o postulante tivesse uma série de características que o distinguisse do cidadão comum, fosse indicado por antigos membros e, por fim, ter sua inclusão submetida a aprovação dos demais associados. Quase cento e cinquenta anos depois, em 1807, foi criada a Geological Society of London, primeira sociedade geológica da história, vista por alguns membros da Royal Society como uma dissidência desnecessária. A princípio, era um clube de treze membros que se propunham a discutir geologia em jantares prazerosos regados a vinho e boa comida. Os critérios de seleção de seus associados eram semelhantes ao da Royal Society e os custos elevados dos jantares dificultavam a participação de aspirantes de baixos recursos financeiros. Apesar dessa restrição, em poucos anos a Geological Society se tornou uma instituição relevante no meio científico e em uma década o número de sócios passou de treze a quatrocentos ultrapassando setecentos nos 1830s.

As reuniões, a princípio semanais, passaram a ser mensais e abertas ao público convidado, que assistia às discussões, quase sempre acaloradas, entre partidários de opiniões divergentes. Assim como na Royal Society, não era permitida a participação de mulheres. A presença feminina somente foi admitida em ambas as instituições a partir de 1919, por imposição de uma lei.

Modelos semelhantes de sociedades científicas foram adotados em diversos países ao longo dos séculos dezoito e dezenove. Contudo, em um mundo que se industrializava a uma grande velocidade, a restrição a participação pública não atendia a demanda por conhecimento de todas as camadas sociais. Assim, por iniciativa de um grupo de gentlemen britânicos foi criada, em 1831, a British Association for the Advancement of Science (BAAS), com a proposta de expandir a cultura e o saber além das universidades e dos grandes centros urbanos. Diferindo da Geological Society, cujas reuniões aconteciam sempre em Londres, a BAAS passou a organizar encontros itinerantes e abertos ao público geral permitindo, também, a participação de mulheres. Em um período de grandes descobertas paleontológicas, de definição das colunas estratigráficas mundiais e de aceleração industrial, com novas fábricas consumindo grandes volumes de carvão e ferro, as seções de geologia eram das mais concorridas nos encontros da BASS, atraindo milhares de pessoas. Com enfoque prático, proprietários de terra tinham grande interesse pelas novas metodologias de prospecção baseadas em relações estratigráficas e, no âmbito filosófico e cultural, as descobertas geológicas abriam novas perspectivas sobre a evolução da Terra, revelando cenários, climas e animais exóticos que mexiam com o imaginário popular. 
No Brasil, assim como em diversos países, as sociedades geológicas foram espelhadas nas primeiras sociedades inglesas e atualmente adotam a proposta de itinerância da BAAS. Tanto a Sociedade Brasileira de Geologia como seus núcleos regionais organizam encontros em intervalos de dois anos onde são apresentados resultados de pesquisas e discutidos temas relevantes na área de Ciências da Terra. Mas qual a razão da itinerância? No caso das reuniões da SBG, a mudança dos locais de encontro permite que cada estado mantenha sua representatividade científica e política no cenário nacional. Outras razões podem ser apontadas, entre as quais a observação direta do contexto geológico da região, a existência de sítios de interesse acadêmico, a vocação turística da cidade ou mesmo a facilidade de acesso ao local. Os simpósios coordenados pelos núcleos regionais, da mesma forma, não ocorrem apenas nas capitais, mas em uma grande diversidade de municípios. Não é incomum, nesses encontros, a reunião dos participantes em hotel ou instituição, em uma situação de quase isolamento em relação à população local, gerando situações como o espanto de uma professora de ensino fundamental indignada com o "evento absurdo" que ocorria em determinado momento em uma pequena cidade do interior do Brasil. Ao tentar participar do evento, a professora havia sido alertada pelos organizadores de que o mesmo não era gratuito, sendo necessária uma inscrição e um crachá a fim de ter franqueada sua participação no evento, gerando surpresa e revolta.

Essa situação revela muito da falta de interação entre a comunidade científica e a população, contrariando as razões primordiais da itinerância. É fato que muitos encontros são realizados em locais que, apesar de apresentarem paisagem exuberante, são habitados por uma população de baixo poder aquisitivo e com poucos recursos na área de educação. A questão que aqui se apresenta é: além do benefício econômico efêmero resultante da hospedagem e dos passeios turísticos, qual é a contribuição dos participantes àa comunidades locais?

A percepção é de que a razão principal da itinerância na forma como proposta originalmente no século dezenove, ou seja, o de promover o intercâmbio de conhecimento com diversos níveis da sociedade em diferentes regiões, está sendo negligenciada. $\mathrm{O}$ mecanismo de funcionamento destes encontros, cujos participantes, em sua maioria, são provenientes de universidades públicas, não reflete a dimensão que deveria ser dada a cada elemento do propalado "tripé" ensino-pesquisa-extensão. É necessário desenvolver novas propostas de interação com o público, como a realização de palestras de conteúdo científico, exposição de coleções e minicursos destinados à públicos de diferentes níveis de conhecimento. 